\title{
An alternative spliced variant of circulating soluble tumor necrosis factor- $\alpha$ receptor- 2 is paradoxically associated with insulin action
}

\author{
José Manuel Fernández-Real, Marek Straczkowski ${ }^{1}$, Begoña Lainez, Matilde R Chacón ${ }^{2}$, Irina Kowalska ${ }^{1}$, \\ Abel López-Bermejo, Antonio García-España ${ }^{2}$, Agnieszka Nikolajuk ${ }^{1}$, Ida Kinalska ${ }^{1}$ and Wifredo Ricart \\ Section of Diabetes, Endocrinology and Nutrition, University Hospital of Girona 'Dr. Josep Trueta', Ctra. França s/n, 17007 Girona, Spain, ${ }^{1}$ Department \\ of Endocrinology, Diabetology and Internal Medicine, Medical Academy, Bialystok, Poland and ${ }^{2}$ Endocrinology and Research Unit, Hospital Universitari \\ Joan XXIII from Tarragona, Rovira i Virgili University, Spain \\ (Correspondence should be addressed to J M Fernández-Real; Email: uden.jmfernandezreal@htrueta.scs.es)
}

\begin{abstract}
Objective: Serum concentrations of soluble tumor necrosis factor- $\alpha$ (TNF- $\alpha$ ) receptor 2 (sTNFR2) are associated with insulin resistance. In a recent study, we provided evidence for the existence of a biologically active form of sTNFR2 produced by alternative splicing (DS-TNFR2). We aimed to evaluate whether this circulating DS-TNFR2 is associated with insulin action in humans.

Design and methods: Real time PCR (light cycler technology) evaluated DS-TNFR2 expression in monocytes. DS-TNFR2 was measured using a monoclonal antibody against an epitope present in TNFR2 (first 14 residues of the juxtamembrane region) but predicted to be absent in soluble proteolytic cleavage-produced TNFR2. Insulin sensitivity was measured using euglycemic hyperinsulinemic clamp $(n=76)$ and homeostatic model of assessment (HOMA) value in a replication study of 223 subjects. Results: Real time PCR confirmed gene expression of DS-TNFR2 in monocytes from healthy subjects. A significant and positive association was found between serum DS-TNFR 2 concentration and insulin sensitivity $(P=0.032, n=76)$. This association was most significant in subjects with normal glucose tolerance $(r=0.44, \quad P=0.002)$. The subjects in whom DS-TNFR2 was detectable were more insulin sensitive than those with undetectable DS-TNFR2 $(42.12 \pm 22.08$ vs $31.71 \pm$ $\left.16.95 \mu \mathrm{mol} \times \mathrm{kg}^{-1} \times \mathrm{min}^{-1}, P=0.039\right)$. DS-TNFR2 was inversely associated with body mass index, waist-to-hip ratio, systolic and diastolic blood pressure, fasting serum glucose, serum triglycerides and serum uric acid concentration and with the HOMA value $(P=0.03)$ in the replication study. Circulating DS-TNFR2 declined with increased number of components of the metabolic syndrome. Conclusion: Native sTNFR2 and DS-TNFR2 show opposite associations with insulin action. DS-TNFR2 might play a role as a counterpart of the proinflammatory environment associated with insulin resistance.
\end{abstract}

European Journal of Endocrinology 154 723-730

\section{Introduction}

There is some evidence that tumor necrosis factor- $\alpha$ $(\mathrm{TNF}-\alpha)$ expression is increased in the muscle and adipose tissue of obese humans and patients with type 2 diabetes when compared with lean individuals $(1-5)$, although not all studies are concordant (6). TNF- $\alpha$ binds to two TNF- $\alpha$ receptors, TNF-R1 and TNF-R2. Each receptor is expressed by most cells and can be regulated independently. An important feature to the pathophysiology of obesity, is that RNA transcripts encoding TNFR2 receptors are significantly increased in fat and muscle tissues of obese and diabetic animals and humans compared with lean individuals (7).

After binding to its receptors, a proteolytic cleavage of the extracellular parts elicits the soluble forms named $(8,9)$ sTNFR1 (60 kDa) and sTNFR2 (80 kDa). This process is known as shedding. The concentration of these soluble TNF- $\alpha$ receptors (sTNFRs) is proportional to previous TNF- $\alpha$ action. In fact, sTNFRs remain elevated in plasma for longer periods of time after the administration of TNF- $\alpha$, and are thought to be a surrogate of previous TNF- $\alpha$ effects (8). For instance, sTNFRs were constantly found in the circulation in patients with sepsis, reflecting the inflammatory state even when TNF activity was undetectable (10). TNF- $\alpha$ circulates and bind to sTNFRs, which appears to alter its clearance rate and/or enhance its biological activity. sTNFRs affect TNF- $\alpha$ function by stabilizing its activity, most likely by preventing dissociation of the homotrimeric TNF- $\alpha$ molecules to inactive monomers. sTNFRs also represent a buffer system that prolongs the biological effects of 
TNF- $\alpha$ by forming a slow release reservoir and impeding spontaneous denaturation of the cytokine $(8,11,12)$. In this sense, serum concentrations of sTNFR 2 were proportional to BMI and insulin resistance in healthy obese and lean subjects, and were increased in subjects with type 2 diabetes $(13-24)$.

Support for the importance of TNF- $\alpha$ in metabolism has been recently obtained by the interaction between defective insulin action and loss of control of TACE (TNF- $\alpha$-converting enzyme), a protease that regulates soluble TNF- $\alpha$ levels and TNFR2 shedding (25). Uncontrolled TACE protease activity led to increasing levels of circulating soluble TNF- $\alpha$, vascular inflammation and glucose intolerance in an animal model (26).

Shedding and alternative splicing, the two mechanisms of producing soluble transmembrane receptors, are not mutually exclusive. Alternative splicing is a powerful and versatile regulatory mechanism that affects quantitative control gene expression and functional diversification of protein (27). Other members of the TNF receptor family and several cytokine receptors that are found as soluble receptors are generated by alternative splicing $(28-31)$. We recently identified a biologically active soluble TNF- $\alpha$ receptor 2 isoform (DS-TNFR2) that was generated by alternative splicing and that antagonised TNF- $\alpha$ action in in vivo studies (32).

DS-TNFR2 was present in the serum of healthy individuals (32). We aimed to a) confirm the existence of DS-TNFR2 mRNA in peripheral monocytes from healthy subjects; and b) to evaluate circulating DS-TNFR2 in association with insulin action in vivo.

\section{Subjects and methods}

\section{Isolation of peripheral blood mononuclear cells (PBMC) and RNA extraction}

PBMC were isolated from $40 \mathrm{ml}$ of blood by density centrifugation using Histopaque 1077 (Sigma-Aldrich, Sant Louis, MO, USA), following manufacturer's instructions. After centrifugation, mononucleated cells were recovered and washed twice in one volume of PBS. The cell yield was $10^{6}$ cells $/ \mathrm{ml}$ of blood. The cells were re-suspended in RPMI-1640 medium (Gibco, Invitrogen Corporation, CA, USA) supplemented with $5.5 \mathrm{mM}$ glucose, $10 \%$ heat inactivated foetal calf serum (Gibco), $50 \mu \mathrm{g} / \mathrm{ml}$ gentamicin (Sigma), $20 \mathrm{mM}$ HEPES (Sigma), $3 \mathrm{mM}$ glutamine and plated in six wheel plates (Corning Costar, Acton, MA, USA) at $1 \times 10^{7}$ cells for $3 \mathrm{ml}$ media. The plates were incubated for $1 \mathrm{~h}$ at $37^{\circ} \mathrm{C}$ in $5 \% \quad \mathrm{CO}_{2}$ to allow for monocyte attachment. The attached monocytes $(8-10 \%$ of total cell number) were washed on the plates four times with PBS to remove any other cell. Monocytes cells were treated with $1 \mu \mathrm{g} / \mathrm{ml}$ lipopolysaccharide (LPS) from Escherichia coli $026: \mathrm{B} 26$ at $37^{\circ} \mathrm{C} 5 \% \mathrm{CO}_{2}$ for $4 \mathrm{~h}$.
Total RNA was extracted from cells by using RNAsy Mini Kit (Qiagen) following manufacturer's instructions. Total RNA was treated with 30 units of RNase-free DNAse (Qiagen) prior column elution, in order to avoid contamination with genomic DNA. RNA integrity was electrophoretically verified by ethidium bromide staining and by $\mathrm{OD}_{260} / \mathrm{OD}_{280} \mathrm{~nm}$ absorption ratio

One $\mu \mathrm{g}$ of RNA was reverse transcribed (RT) using Promega reverse transcription system (Promega), $20 \mu \mathrm{l}$ of RT mixture contained: $1 \times$ RT-buffer $(10 \mathrm{mM}$ Tris-HCl pH 9.0, $50 \mathrm{mM} \mathrm{KCl,} \mathrm{0.1 \%} \mathrm{Triton} \mathrm{X-100),}$ $1 \mathrm{mM}$ of each dNTP, $1 \mathrm{U} / \mu \mathrm{l}$ recombinant RNAsin Ribonuclease inhibitor, $15 \mathrm{U}$ of AMV reverse transcriptase, $0.5 \mu \mathrm{g}$ of random primers. The cDNA reaction was incubated for $10 \mathrm{~min}$ at $25^{\circ} \mathrm{C}$, followed by $60 \mathrm{~min}$ at $42{ }^{\circ} \mathrm{C}$ and heated $5 \mathrm{~min}$ at $95^{\circ} \mathrm{C}$.

\section{Primer design and light cycler amplification}

The primer pairs for TNFR2 (and DS-TNFR2) were selected with the assistance of Primer3 primer design on line software (http://www.broad.mit.edu/cgi-bin/ primer/primer3_www.cgi). The primer sequences used in this study were: Oligo sense LC1: 5'-CGTTCTCC AACACGACTTCA- 3' Oligo antisense LC1: 5'-CTTATCGGCAGGCAAGTG AGG-3'.

Amplification of the cDNA coding for TNFR2 DS-TNFR2 was performed using LightCycler technology (Roche Diagnostics, Basel, Switzerland). The reactions were performed in a volume of $20 \mu \mathrm{l}$ of a mixture containing $0.5 \mu \mathrm{M}$ of each oligonucleotide primer and $2 \mu \mathrm{l}$ of DNA LC-FastStart DNA Master SYBR green I (Roche) containing Taq DNA polymerase, reaction buffer, dNTP mix and the double stranded DNA (dsDNA)-specific fluorescent dye SYBR green I. The concentration of $\mathrm{MgCl}_{2}$ was adjusted to $4 \mathrm{mM}$. Dimethyl sulfoxide was added at $5 \%$ final concentration. LightCycler mastermix (18 $\mu \mathrm{l})$ was filled in the LightCycler glass capillaries and $2 \mu \mathrm{l}$ cDNA was added as PCR template. The following LightCycler protocol was used $95^{\circ} \mathrm{C}$ for $10 \mathrm{~s}$; denaturation, $63^{\circ} \mathrm{C}$ for $5 \mathrm{~s}$; annealing, $72^{\circ} \mathrm{C}$ for $10 \mathrm{~s}$; elongation, $84^{\circ} \mathrm{C}$ for $2 \mathrm{~s}$.

\section{Fluorescence acquisition}

Melting curve program $70-99^{\circ} \mathrm{C}$ with a heating rate of $0.1^{\circ} \mathrm{C} / \mathrm{s}$ and continuous fluorescence measurements and a final program down to $40^{\circ} \mathrm{C}$. To avoid detection of non-specific PCR products, the purity of each amplified product was confirmed by agarose gel analysis and by melting curve analysis according to manufacturer's protocol.

\section{Subjects}

DS-TNFR2 was analyzed in 299 consecutive Caucasian subjects with the following inclusion criteria: 1) $\mathrm{BMI}<40 \mathrm{~kg} / \mathrm{m}^{2}, 2$ ) absence of systemic disease, and 3) absence of infection within the previous month. None 
of the control subjects were under medication or had evidence of metabolic disease other than obesity. Alcohol and caffeine were withheld within $12 \mathrm{~h}$ of performing the insulin sensitivity test. Smokers were defined as any person consuming at least 1 cigarette a day in the previous 6 months. Liver disease and thyroid dysfunction were specifically excluded by biochemical work-up.

All nondiabetic subjects had fasting plasma glucose $<7.0 \mathrm{mM}$ and two-hour post-load plasma glucose $<11.1 \mathrm{mM}$ after a $75 \mathrm{~g}$ oral glucose tolerance test. Glucose intolerance and type 2 diabetes were diagnosed according to the American Diabetes Association Criteria during an oral glucose tolerance test. All subjects with abnormal glucose tolerance were diagnosed during this test and had no known previous alterations.

All subjects gave written informed consent after the purpose of the study was explained to them. The institutional review boards of the participant institutions approved the protocol.

\section{Study of insulin sensitivity}

Insulin sensitivity was measured using the euglycemic hyperinsulinemic clamp technique as previously reported (21-23). The rate of whole-body glucose uptake ( $\mathrm{M}$ value) was calculated as the mean glucose infusion rate from 80 to $120 \mathrm{~min}$ and normalized for fat-free mass. Blood samples for the determination of DS-TNFR2 were taken before and after clamp, and frozen at $-70{ }^{\circ} \mathrm{C}$.

In the replication study $(n=223)$, the homeostatic model of assessment (HOMA) index was calculated using the formula: HOMA $=$ (fasting glucose $(\mathrm{mmol} / \mathrm{l}) \times$ fasting insulin $(\mathrm{mU} / \mathrm{l})) / 22.5$.

\section{Analytical methods}

Serum glucose, insulin, cholesterol, high-density lipoprotein-cholesterol (HDL-C), triglycerides, uric acid, and C-reactive protein (CRP) were measured as previously reported $(18,22)$.

Serum soluble TNF- $\alpha$ receptor 1 (sTNFR1) and sTNFR 2 levels were also analysed using EASIA (Medgenix and BioSource Europe S.A., Zoning Industriel B-6220, respectively, Fleunes, Belgium) and adiponectin (LINCO Research Inc. St Charles, MO, USA) were also measured as previously published $(18,22)$.

\section{ELISA of TNFR2 Isoform (generated by alternative splicing)}

The conventional ELISA systems that measure soluble sTNFR2 do not differentiate between the soluble receptor generated by alternative splicing (DS-TNFR2) and the proteolytical cleavage (PC-TNFR2). We produced a monoclonal antibody against an epitope present in TNFR2 (first 14 residues of the juxtamembrane region) which is predicted to be absent in soluble PC-TNFR2 (32). In order to demonstrate that this ELISA was not detecting PC-TNFR2, we induced TNFR2 shedding from several cells in vitro, including TNFR2-transfected COS-7 cells, PBMC and U937 cells, using phorbol-myristate acetate. The DS-TNFR2 ELISA did not detect shedded TNFR2 from any of these cellular types (32).

\section{Statistical methods}

Descriptive results of continuous variables are expressed as mean \pm S.D. Before statistical analysis, normal distribution and homogeneity of the variances were evaluated using Levene's test and then variables were given a logtransformation if necessary. These parameters (insulin sensitivity, triglycerides, sTNFR1, sTNFR2, DS-TNFR2 and adiponectin) were analysed on a log scale and tested for significance on that scale. The anti-log transformed values of the means are reported in the tables. For values of DS-TNFR2 below the sensitivity of the assay, a value of 0.001 was considered for statistical analysis. Relation between variables were tested using Pearson's test and stepwise multiple linear regression analysis. We used chi-square test for comparisons of proportions, and unpaired or paired $t$-tests for comparisons of quantitative variables. The analysis were performed using the program SPSS (version 11.0, SPSS Inc., Chicago, IL, USA).

\section{Results}

\section{Qualitative determination of DS-TNFR2 by light cycler technology}

Real time PCR confirmed the mRNA expression of DSTNFR2 in PBMC and monocytes. Two fragments of different size were generated. Two $419 \mathrm{bp}$ and a $306 \mathrm{bp}$ fragments, corresponding to the wild form of TNFR2 or to the alternative spliced DS-TNFR2 were observed (Fig. 1A). In the analysis of the melting curves, 2 melting peaks were obtained corresponding to both amplified fragments The melting temperatures were for DS-TNFR2 $(\Delta 7,8) 87.91{ }^{\circ} \mathrm{C}$ and for TNFR2 $91.81^{\circ} \mathrm{C}$, respectively. (Fig. 1B). Different samples, monocytes, monocytes activated with LPS and PBMC from healthy controls were used. In all the used samples the melting analysis detected two peaks corresponding to the wild type and to the alternative spliced DS-TNFR2 (Fig. 1C).

\section{Association between DS-TNFR2 and insulin sensitivity}

DS-TNFR2 was present in 21 out of 76 subjects $(27.63 \%)$, and was significantly and frequently more detectable in women $(P=0.015)$. Baseline and postclamp DS-TNFR2 concentrations were positively related to insulin sensitivity $(r=0.25, \quad P=0.032$ and 
A

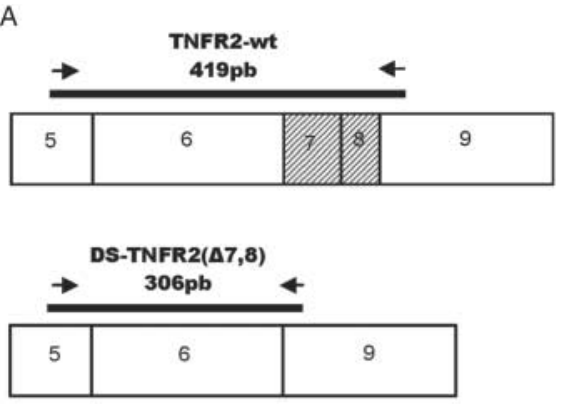

B

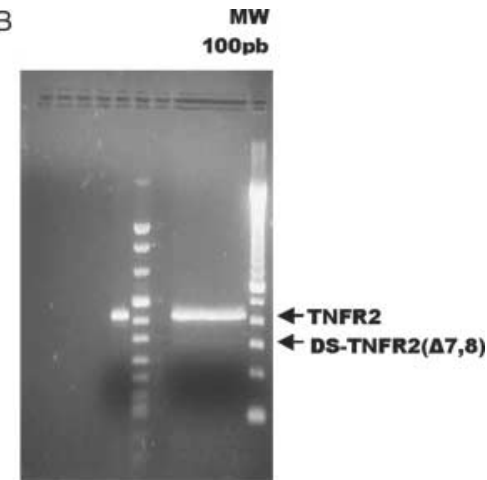

C

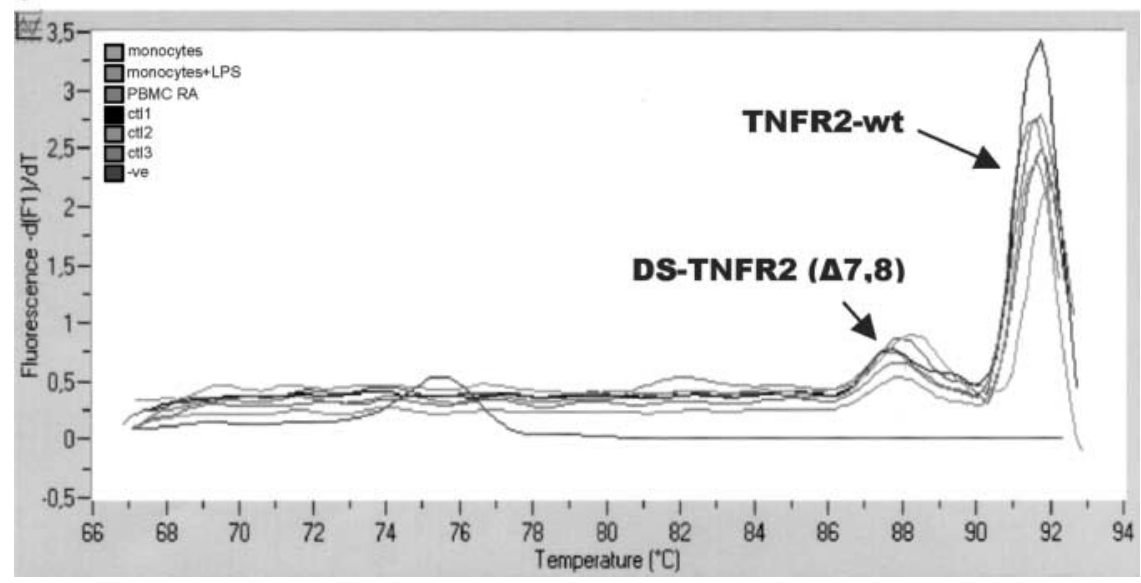

Figure 1 Qualitative determination of DS-sTNFR2 $(\Delta 7,8)$ by light cycler Technology. (A). representation of primers (arrows) used for the amplification of the TNFR2 and spliced isoform DS-sTNFR2 $(\Delta 7,8)$, indicating the size of the amplified region. (B) $3 \%$ agarose gel visualizing the amplified fragments. (C) melting point analysis of the light cycler amplified products of different samples.

$r=0.24, P=0.038$, respectively). DS-TNFR2-positive subjects were more insulin sensitive than those subjects with undetectable DS-TNFR2 (42.12 222.08 vs $31.71 \pm 16.95 \mu \mathrm{mol} \times \mathrm{kg}_{\mathrm{ffm}}^{-1} \times \mathrm{min}^{-1}, \quad$ respectively
$P=0.039)$. This difference persisted in subjects with normal glucose tolerance $(n=51)$, shown in Table 1 $(P=0.01)$. Among these subjects, the relationship between DS-TNFR2 concentration and insulin

Table 1 Anthropometrical and biochemical characteristics according to detectable or undetectable serum DS-TNFR2. Only subjects with normal glucose tolerance are shown $(n=51)$.

\begin{tabular}{|c|c|c|c|}
\hline & Undetectable DS-TNFR2 & Detectable DS-TNFR2 & $P$-value \\
\hline$n$ & 36 & 15 & - \\
\hline Sex (male/female) & $23 / 13$ & $4 / 11$ & 0.015 \\
\hline Age (years) & $33.56 \pm 7.35$ & $34.33 \pm 8.15$ & NS \\
\hline $\mathrm{BMI}\left(\mathrm{kg} / \mathrm{m}^{2}\right)$ & $26.86 \pm 5.28$ & $26.65 \pm 6.81$ & NS \\
\hline WHR & $0.85 \pm 0.08$ & $0.81 \pm 0.07$ & NS \\
\hline Percent body fat & $24.94 \pm 11.28$ & $26.12 \pm 13.57$ & NS \\
\hline $\mathrm{HbA}_{1 \mathrm{c}}(\%)$ & $5.49 \pm 0.51$ & $5.59 \pm 0.43$ & NS \\
\hline Fasting plasma glucose (mmol) & $5.14 \pm 0.65$ & $4.97 \pm 0.39$ & NS \\
\hline Fasting plasma insulin (pmol//) & $86.32 \pm 59.59$ & $82.45 \pm 65.02$ & NS \\
\hline$M$ value $\left(\mu \mathrm{mol} \times \mathrm{kg}_{\mathrm{ffm}}^{-1} \times \min ^{-1}\right)$ & $38.22 \pm 16.29$ & $53.01 \pm 17.79$ & 0.01 \\
\hline Cholesterol $(\mathrm{mmol} / \mathrm{l})$ & $4.89 \pm 0.93$ & $4.53 \pm 0.80$ & NS \\
\hline Triglycerides (mmol//) & $1.30 \pm 0.86$ & $1.18 \pm 0.61$ & NS \\
\hline $\mathrm{HDL}-\mathrm{C}(\mathrm{mmol} / \mathrm{l})$ & $1.36 \pm 0.39$ & $1.23 \pm 0.35$ & NS \\
\hline LDL-C (mmol/l) & $2.97 \pm 0.87$ & $2.82 \pm 0.74$ & NS \\
\hline TNF $\alpha(\mathrm{pg} / \mathrm{ml})$ & $0.43 \pm 0.42$ & $0.30 \pm 0.43$ & NS \\
\hline sTNFR1 (ng/ml) & $2.17 \pm 0.46$ & $2.20 \pm 0.43$ & NS \\
\hline sTNFR2 (ng/ml) & $4.27 \pm 1.10$ & $4.76 \pm 1.20$ & NS \\
\hline DS-TNFR2 $(\mathrm{ng} / \mathrm{ml})^{*}$ & 0.01 & $1.18-5.1$ & $<0.00001$ \\
\hline
\end{tabular}

* Interquartile range; NS, not significant. 
Table 2 Anthropometrical and biochemical characteristics according to detectable or undetectable serum DS-TNFR2 in the replication study.

\begin{tabular}{lccc}
\hline & Undetectable DS-TNFR2 & Detectable DS-TNFR2 & P-value \\
\hline$n$ & 134 & 89 & - \\
Sex (male/female) & $100 / 34$ & $38 / 51$ & 0.006 \\
Type 2 diabetes & $40(74 \%)$ & $15(26 \%)$ & \\
Nondiabetic subjects & $94(56 \%)$ & $74(44 \%)$ & 0.01 \\
\hline
\end{tabular}

sensitivity was most significant $(r=0.44, P=0.002$, and $r=0.48, P=0.0005$, baseline and post-clamp, respectively). We also observed a positive relationship between baseline DS-TNFR2 levels and fat-free mass $(r=0.64, P=0.025)$, and between DS-TNFR2/native TNFR2 ratio, and fasting and post-load glucose concentrations $(r=-0.58, \quad P=0.048$ and $r=-0.62$, $P=0.033$, respectively) in these subjects.

In subjects with glucose intolerance, we also observed increased age and sex-adjusted HDL-C concentrations in DS-TNFR2-positive subjects compared to those with undetectable DS-TNFR2 $(1.35 \pm 0.28$ vs $1.07 \pm 0.24 \mathrm{mmol} / \mathrm{l}, P=0.027$, respectively).

The association of the DS-TNFR2/native TNFR2 ratio with CRP nearly reached the level of significance $(r=-0.54, P=0.07)$.

\section{Replication study}

Circulating DS-TNFR 2 was detected in $40 \%$ of consecutive 223 healthy subjects (Tables 2 and 3). Mean serum DS-TNFR2 concentration was significantly greater in women than men $(2.3 \pm 3.8 \mathrm{ng} / \mathrm{ml}$ vs $1.6 \pm 4.2$, $P=0.03)$, in nondiabetic than in subjects with type 2 diabetes $(2.1 \pm 4.4 \mathrm{ng} / \mathrm{ml}$ vs $0.73 \pm 2.5, P=0.004)$ (Table 2), and in nonsmoking subjects compared with smokers $(2.3 \pm 4.6 \mathrm{ng} / \mathrm{ml}$ vs $1.1 \pm 3.1, P=0.03)$.

Serum DS-TNFR2 correlated with age $(r=-0.19$, $P=0.004), \quad$ BMI $\quad(r=-0.15, \quad P=0.02), \quad$ waist $(r=-0.20, P=0.004)$, waist-to-hip ratio $(r=-0.21$, $P=0.003)$ and systolic and diastolic blood pressure $(r=-0.14$ and $-0.16, P=0.05$ and $P=0.02$, respectively). Circulating DS-TNFR2 concentration was also associated with fasting glucose $(r=-0.15, P=0.02)$, triglycerides $(r=-0.18, \quad P=0.008)$ and uric acid $(r=-0.18, P=0.008)$.

In nondiabetic subjects, the associations with waist $(r=-0.17, P=0.03)$, waist-to-hip ratio $(r=-0.20$, $P=0.01), \quad$ diastolic blood pressure $(r=-0.15$ $P=0.04)$, fasting triglycerides $(r=-0.19, P=0.02)$ and uric acid $(r=-0.18, P=0.03)$ remained significant. In a multiple linear regression analysis, waist $(P=0.04)$ contributed to $15 \%$ of DS-TNFR2 variance after controlling for age, BMI, systolic and diastolic blood pressure, and fasting glucose and triglycerides.

As DS-TNFR2 was more frequently detected in women than in men, we repeated the analyses separately in men and women. Men with the detectable isoform were leaner $\left(25.1 \pm 4.2\right.$ vs $\left.26.7 \pm 3.7 \mathrm{~kg} / \mathrm{m}^{2}, P=0.02\right)$ and younger $(41.7 \pm 13.7$ vs $46.7 \pm 12.4, P=0.03)$. After controlling for age , only BMI contributed significantly to $3 \%$ of DS-TNFR2 variance. Men with the detectable isoform also had lower age-adjusted fasting glucose $(5.5 \pm 1.7$ vs $6.2 \pm 2.3 \mathrm{mmol} / \mathrm{l}, P=0.04$ ), lower fasting triglycerides $(100.6 \pm 52.8$ vs $137.4 \pm 93.2 \mathrm{mg} / \mathrm{dl}, P=0.007)$ and higher serum adiponectin concentration $(13.6 \pm 6.6$ vs $10 \pm 6.6 \mathrm{ng} / \mathrm{ml}, P=0.009)$ than the

Table 3 Anthropometrical and biochemical characteristics according to detectable or undetectable serum DS-TNFR2 in nondiabetic subjects in the replication study.

\begin{tabular}{|c|c|c|c|}
\hline & Undetectable DS-TNFR2 & Detectable DS-TNFR2 & $P$-value \\
\hline$n$ & 94 & 74 & - \\
\hline Age (years) & $41.4 \pm 11.1$ & $38.5 \pm 11.9$ & NS \\
\hline $\mathrm{BMI}\left(\mathrm{kg} / \mathrm{m}^{2}\right)$ & $25.6 \pm 4.4$ & $24 \pm 3.9$ & 0.01 \\
\hline Waist-to-hip ratio & $0.93 \pm 0.07$ & $0.91 \pm 0.07$ & 0.058 \\
\hline Fasting plasma glucose (mmol) & $5.02 \pm 0.6$ & $4.88 \pm 0.6$ & 0.1 \\
\hline Fasting plasma insulin (pmol/l) & $94 \pm 42$ & $89 \pm 37$ & NS \\
\hline Cholesterol (mmol/l) & $5.01 \pm 0.76$ & $4.93 \pm 0.63$ & NS \\
\hline Triglycerides (mg/dl) & $111 \pm 69$ & $85.7 \pm 42$ & 0.0007 \\
\hline $\mathrm{HDL}-\mathrm{C}(\mathrm{mmol} / \mathrm{l})$ & $1.17 \pm 0.29$ & $1.09 \pm 0.3$ & NS \\
\hline LDL-C (mmol/l) & $3.01 \pm 0.91$ & $2.95 \pm 0.85$ & NS \\
\hline sTNFR1* (ng/ml) & $1.7-2.4$ & $1.7-2.3$ & NS \\
\hline sTNFR2* (ng/ml) & $2.75-3.87$ & $2.92-4.15$ & NS \\
\hline Adiponectin (ng/ml) & $11.8 \pm 7.4$ & $14.3 \pm 6.6$ & 0.02 \\
\hline DS-TNFR2* (ng/ml) & 0.01 & $1.01-5.88$ & 0.00001 \\
\hline
\end{tabular}

*Interquartile range; NS, not significant. 

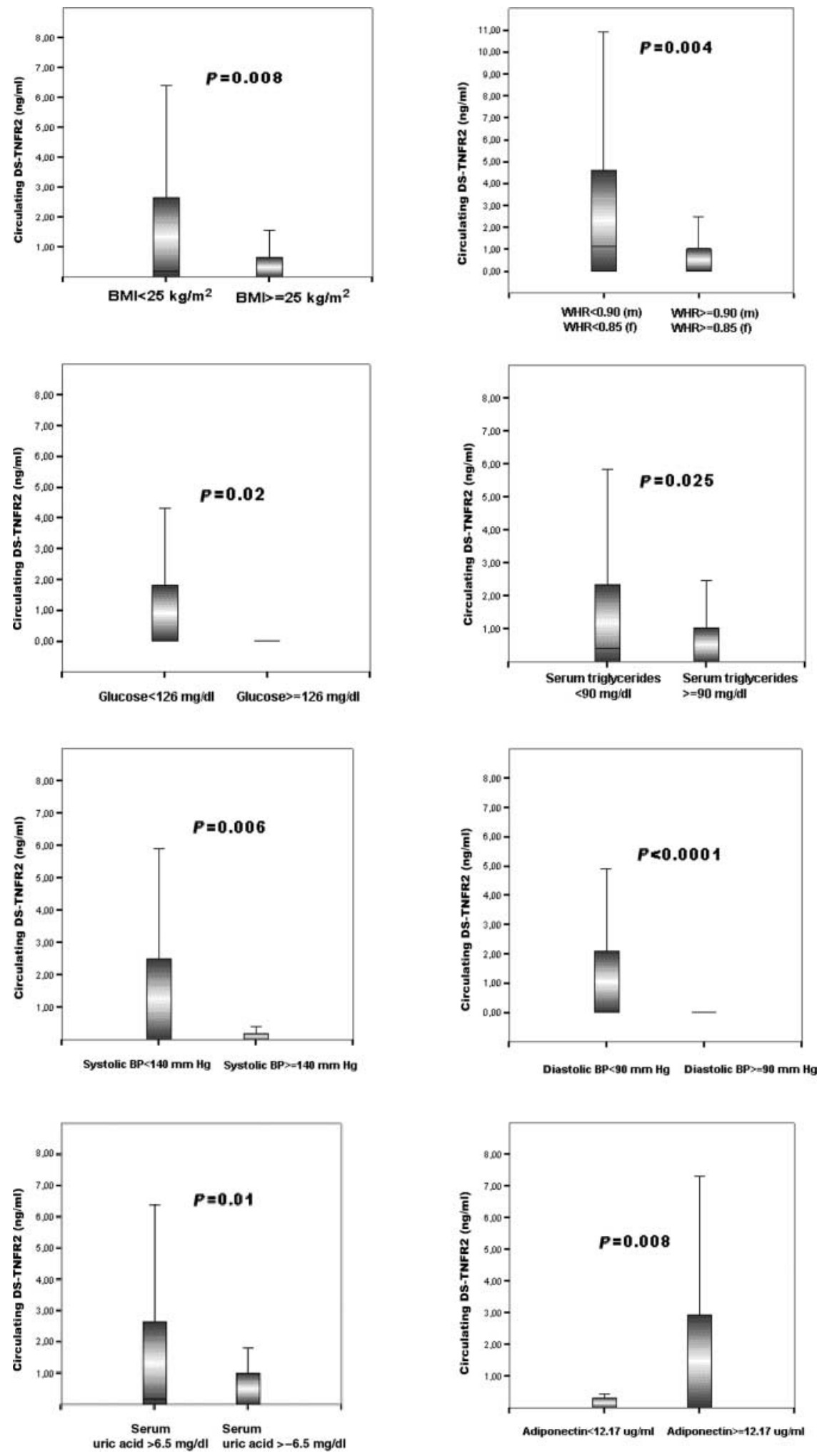

Figure 2 Age and sex-adjusted serum soluble TNFR2 isoform concentration (DS-TNFR2) according to several individual components of the metabolic syndrome in the second study. The bars indicate 50 and 95th percentile of DS-TNFR2 for each category. Subjects were divided into categorical variables corresponding to standard criteria. For triglycerides and adiponectin, subjects were divided according to 50th percentile of the sample. For serum uric acid, $6.5 \mathrm{mg} / \mathrm{dl}$ corresponds to 50 th percentile in men, and 75 th percentile in women. BMI, body mass index; WHR, waist-to-hip ratio; $\mathrm{m}$, males; f, females. 
remaining subjects. These results could not be seen in women. However, the number of women that were studied was relatively low compared with men.

Serum adiponectin correlated with circulating DSTNFR2 in nondiabetic subjects $(r=0.20, P=0.01$, $n=145$ ), and was significantly increased in those subjects with detectable DS-TNFR2 (14.3 \pm 6.6 vs $11.8 \pm 7.4 \mu \mathrm{g} / \mathrm{ml}, \quad P=0.02)$. In fact, adiponectin emerged as the most significant factor influencing DSTNFR2, when it was added as independent variable in the multiple linear regression model specified above, contributing to $23 \%$ of DS-TNFR 2 variance in men.

Serum DS-TNFR2 was significantly associated with the HOMA value $(r=-0.19, P=0.03, n=124)$. Serum DS-TNFR2 declined with increasing components of the metabolic syndrome.

In Fig. 2, age and sex-adjusted serum DS-TNFR2 concentration, according to several individual components of the metabolic syndrome are shown. Those subjects with three or more components of the metabolic syndrome, had significantly decreased circulating DS-TNFR2 levels $(0.91 \pm 2.8 \mathrm{ng} / \mathrm{ml}$ vs $2.13 \pm 4.4$, $P=0.002)$.

No significant associations between sTNFR 1 and DSTNFR2 $(r=-0.03, P=0.64)$ or between sTNFR2 and DS-TNFR2 $(r=0.09, P=0.25)$ were observed.

\section{Discussion}

In this study we have demonstrated detectable serum levels of a novel alternatively spliced human TNFR2 isoform (DS-TNFR2), which was present in 26\% of samples from patients with type 2 diabetes and $44 \%$ of nondiabetic subjects. The cDNA encoding DSTNFR2 lacks exons 7 and 8 (32). The splicing event was such that the amino terminus residues of the extracellular domain of full-length TNFR2, remained exactly the same. We confirmed the presence of DS-TNFR2 in PBMC of healthy subjects by light cycler technology. Interestingly, we observed relationships of DS-TNFR2 with direct measurements of insulin sensitivity. These findings suggest a novel role for DS-TNFR2 in the complex mechanisms that interact with the development of insulin resistance.

We suggest that those subjects with detectable DSTNFR2 would be able to antagonize TNF- $\alpha$ biological activity more efficiently. This happens more frequently in the most insulin sensitive subjects: women, lean subjects, those with lower waist-to-hip ratio, lower blood pressure and lower plasma triglycerides concentrations. The prominent role of DS-TNFR2 in central obesity was suggested by the finding of waist size as an independent and unique determinant of DS-TNFR2. An increase in waist size was associated with a progressive decrease in DS-TNFR2 concentration. The possible anti-inflammatory activity of DS-TNFR2 is suggested by a positive correlation between DS-TNFR2 and circulating adiponectin, and by negative correlation (nearly reaching the level of significance) between percent DSTNFR2 and C-reactive protein

In human physiology, there is a continuous balance between pro-inflammatory factors (TNF- $\alpha$ ) and the anti-inflammatory environment. In the lean and insulin-sensitive subject, the anti-inflammatory side would be favored for the production of adiponectin and DS-TNFR2. With increasing BMI, increased concentration of circulating sTNFR2 would prolong the biological effects of TNF- $\alpha$ by forming a slow release reservoir, and impeding spontaneous denaturation of the cytokine $(8,11,12)$. This increased TNF- $\alpha$ action would lead to inflammation and insulin resistance (24).

DS-TNFR2 is not anchored to the cell membrane and is directly secreted into the extracellular milieu after its synthesis (32). This property would avoid TACE effects and suggests an independent regulation of DS-TNFR2 compared with TNF- $\alpha$ and TNFR2.

A better understanding of how production of different sTNFRs isoforms is regulated will contribute to a changed view of TNF- $\alpha$ action in inflammatory diseases. The study of the mechanisms by which the production of DS-TNFR2 is favored could be helpful in the therapy of diseases associated with excess TNF- $\alpha$ action. DS-TNFR2 could be a biological marker for individuals protected from developing the metabolic syndrome. However, it is equally possible that the highest DS-TNFR2 levels result from greater insulin sensitivity and the low levels of TNF- $\alpha$. Furthermore, the low correlation coefficients observed in this study suggest only a weak association, even though statistically significant in the group sizes tested. The biological meaning of such small group differences should be assessed in further studies.

In summary, native sTNFR2 and DS-TNFR2 show opposite associations with insulin action. DS-TNFR2 might play a role as a counterpart of the proinflammatory environment associated with insulin resistance.

Nucleotide sequence data of the gene encoding DS-TNFR2 are available in the DDBJ/EMBL/GenBank databases under the accession number AY148473.

\section{Acknowledgements}

This study was supported by grants from the Ministerio de Educación y Ciencia (BFU2004-03 654) and from the Fondo de Investigaciones Sanitarias, Ministry of Health of Spain: 00/0024-01 and 00/0023-03, G03/212, C03/08 and G03/028, and from the Polish State Committee for Scientific Research: 3 P05B 179 22.The authors declare that there is no, or potential conflict of interest, that would prejudice the impartiality of this study. 


\section{References}

1 Hotamisligil GS, Shargill NS \& Spiegelman BM. Adipose expression of tumor necrosis factor-alpha: direct role in obesitylinked insulin resistance. Science 1993259 87-91.

2 Hotamisligil GS, Peraldi P, Budavari A, Ellis R, White MF \& Spiegelman BM. IRS-1-mediated inhibition of insulin receptor tyrosine kinase activity in TNF- $\alpha$ - and obesity-induced insulin resistance. Science $1996271665-668$.

3 Kern PA, Saghizadeh M, Ong JM, Bosch RJ, Deem R \& Simsolo RB. The expression of tumor necrosis factor in human adipose tisssue. Regulation by obesity, weight loss, and relationship to lipoprotein lipase. Journal of Clinical Investigation 199595 2111-2119.

4 Saghizadeh M, Ong JM, Garvey WT, Henry RR \& Kern PA. The expression of TNF $\alpha$ by human muscle. Relationship to insulin resistance. Journal of Clinical Investigation 199697 1111-1116.

5 Hotamisligil GS, Arner P, Caro JF, Atkinson RL \& Spiegelman BM. Increased adipose tissue expression of tumor necrosis factor- $\alpha$ in human obesity and insulin resistance. Journal of Clinical Investigation $1995952409-2415$.

6 Koistinen HA, Bastard JP, Dusserre E, Ebeling P, Zegari N, Andreelli F, Jardel C, Donner M, Meyer L, Moulin P, Hainque B, Riou JP, Laville M, Koivisto VA \& Vidal H. Subcutaneous adipose tissue expression of tumour necrosis factor-alpha is not associated with whole body insulin resistance in obese nondiabetic or in type-2 diabetic subjects. European Journal of Clinical Investigation $200030302-310$.

7 Hofmann C, Lorenz K, Braithwaite SS, Colca JR, Palazuk BJ, Hotamisligil GS \& Spiegelman BM. Altered gene expression for tumor necrosis factor-alpha and its receptors during drug and dietary modulation of insulin resistance. Endocrinology 1994 $134264-270$.

8 Aderka D, Engelmann H, Maor Y, Brakebusch C \& Wallach D. Stabilization of the bioactivity of tumor necrosis factor by its soluble receptors. Journal of Experimental Medicine 1992175 323-329.

9 Nophar Y, Kemper O, Brakebusch C, Englemann H, Zwang R, Aderka D, Holtmann H \& Wallach D. Soluble forms of tumor necrosis factors (TNF-Rs). The cDNA for the type I TNF-R, cloned using amino acid sequence data of its soluble form, encodes both the cell surface and a soluble form of the receptor. EMBO Journal 19909 3269-3278

10 Schroder J, Stuber F, Gallati H, Schade FU \& Kremer B. Pattern of soluble TNF receptors I and II in sepsis. Infection 199523 $143-148$.

11 Aderka D, Engelmann H, Shemer-Avni Y, Hornik V, Galil A, Sarov B \& Wallach D. Variation in serum levels of the soluble TNF receptors among healthy individuals. Lymphokine Cytokine Research 199211 157-159.

12 Aderka D. The potential biological and clinical significance of the soluble tumor necrosis factor receptors. Cytokine Growth Factor Reviews $19967231-240$.

13 Hotamisligil GS, Arner P, Atkinson RL \& Spiegelman BM. Differential regulation of the p80 Tumor Necrosis Factor Receptor in human obesity and insulin resistance. Diabetes $1997 \mathbf{4 6} 451-455$

14 Fernández-Real JM, Broch M, Ricart W, Casamitjana R, Gutierrez C, Vendrell J \& Richart C. Plasma levels of the soluble fraction of tumor necrosis factor receptor 2 and insulin resistance. Diabetes 199847 1757-1762.

15 Fernández-Real JM, Molina A, Broch M, Ricart W, Gutierrez C, Casamitjana R, Vendrell J, Soler J \& Gomez-Saez JM. The TNF system activity is associated with insulin resistance and dyslipidemia in myotonic dystrophy. Diabetes 199948 1108-1112.

16 Fernández-Real JM, Gutierrez C, Ricart W, Castiñeira MJ, Vendrell J $\&$ Richart C. Plasma levels of the soluble fraction of tumor necrosis factor- $\alpha$ receptors 1 and 2 are independent determinants of total and LDL-Cholesterol concentrations in healthy subjects. Atherosclerosis $1999146321-327$.

17 Fernández-Real JM, Laínez B, Vendrell J. Rigla M, Castro A, Penarroja G, Broch M, Perez A, Richart C, Engel P \& Ricart W.
Shedding of tumor necrosis factor-alpha receptors, blood pressure and insulin sensitivity in type 2 diabetes mellitus. American Journal of Physiology - Endocrinology and Metabolism $2002 \mathbf{2 8 2}$ E952-E959.

18 Fernández-Real JM, López-Bermejo A, Casamitjana R \& Ricart W. Novel interactions of adiponectin with the endocrine system and inflammatory factors. Journal of Clinical Endocrinology and Metabolism $2003 \mathbf{8 8} 2714-2718$.

19 Hauner H, Bender M, Haastert B \& Hube F. Plasma concentrations of soluble TNF-alpha receptors in obese subjects. International Journal of Obesity and Related Metabolic Disorders 199822 1239-1243.

20 Corica F, Allegra A, Corsonello A, Buemi M, Calapai G, Ruello A, Nicita Mauro V \& Ceruso D. Relationship between plasma leptin levels and the tumor necrosis factor- $\alpha$ system in obese subjects. International Journal of Obesity and Related Metabolic Disorders 199923 355-360.

21 Dzienis-Straczkowska S, Straczkowski M, Szelachowska M, Stepien A, Kowalska I \& Kinalska I. Soluble tumor necrosis factor-alpha receptors in young obese subjects with normal and impaired glucose tolerance. Diabetes Care 200326 875-880.

22 Straczkowski M, Kowalska I, Stepien A, Dzienis-Straczkowska S, Szelachowska M \& Kinalska I. Increased plasma-soluble tumor necrosis factor-alpha receptor 2 level in lean nondiabetic offspring of type 2 diabetic subjects. Diabetes Care 200225 1824-1828.

23 Straczkowski M, Kowalska I, Dzienis-Straczkowska S, Stepien A, Skibinska E, Szelachowska M \& Kinalska I. Changes in tumor necrosis factor-alpha system and insulin sensitivity during an exercise training program in obese women with normal and impaired glucose tolerance. European Journal of Endocrinology $2001145273-280$.

24 Fernández-Real JM \& Ricart W. Insulin resistance and chronic cardiovascular inflammatory syndrome. Endocrine Reviews 2003 24 278-301.

25 Crowe PD, Walter BN, Mohler KM, Otten-Evans C, Black RA \& Ware CF. A metalloprotease inhibitor blocks shedding of the 80-kDa TNF receptor and TNF processing in T lymphocytes. Journal of Experimental Medicine $1995 \mathbf{1 8 1} 1205$.

26 Federici M, Hribal ML, Menghini R, Kanno H, Marchetti V, Porzio O, Sunnarborg SW, Rizza S, Serino M, Cunsolo V, Lauro D, Mauriello A, Smookler DS, Sbraccia P, Sesti G, Lee DC, Khokha R, Accili D \& Lauro R. Timp3 deficiency in insulin receptor-haploinsufficient mice promotes diabetes and vascular inflammation via increased TNF-alpha. Journal of Clinical Investigation $20051153494-3505$.

27 Modrek B, Resch A, Grasso C \& Lee C. Genome-wide detection of alternative splicing in expressed sequences of human genes. Nucleic Acids Research 200129 2850-2859.

28 Heaney ML \& Golde DW. Soluble receptors in human disease. Journal of Leukocyte Biology 199864 135-146.

29 Cheng J, Zhou T, Liu C, Shapiro JP, Brauer MJ, Kiefer MC, Barr PJ \& Mountz JD. Protection from Fas-mediated apoptosis by a soluble form of the Fas molecule. Science 1994263 1759-1762.

30 Michel J, Langstein J, Hofstadter F \& Schwarz H. A soluble form of CD137 (ILA/4-1BB), a member of the TNF receptor family, is released by activated lymphocytes and is detectable in sera of patients with rheumatoid arthritis. European Journal of Iттиnology 199828 290-295.

31 Jones SA, Horiuchi S, Topley N, Yamamoto N \& Fuller GM. The soluble interleukin 6 receptor: mechanisms of production and implications in disease. FASEB Journal 200115 43-58.

32 Laínez B, Fernández-Real JM, Romero X, Esplugues E, Ricart W \& Engel P. Identification and expression of a spliced variant that encodes human soluble TNF type 2 receptor. International Iттиnology $200316169-177$

Received 16 November 2005

Accepted 14 February 2006 